\title{
STUDY OF CASTELLATED BEAM USING STIFFENERS: A REVIEW
}

\author{
Siddheshwari. A. Patil ${ }^{1}$, Popat. D. Kumbhar ${ }^{2}$ \\ ${ }^{I}$ PG Scholar, Department of Civil Engineering, RIT Rajaramnagar, Maharashtra, India \\ ${ }^{2}$ Associate Professor, Department of Civil Engineering, RIT Rajaramnagar, Maharashtra, India
}

\begin{abstract}
Now-a-days the use of castellated beam has been admired due to its beneficial functions like light in weight, easy to erect, economical and stronger. The castellated beam is manufactured from its parent solid I beam by cutting it in zigzag pattern and again joining it by welding, so that the depth of the beam increases. Hence, due to increase in depth of beam load carrying capacity of the parent I section is increased with same quantity of material. The increase in depth of castellated beam leads to web post buckling and lateral torsional buckling failure when these beams are subjected to loading. There are many other modes of failure like formation of flexure mechanism, lateral torsional buckling, and formation of vierendeel mechanism, rupture of the welded joint in a web post and shear buckling of a web post which needs to be taken care of. Study shows that use of stiffeners in the web portion of beam helps in minimizing these failures. Therefore, a detailed study in respect of number of stiffeners, size of stiffener and there locations in the web portion of castellated beam needs to be carried out. Hence, in the present paper an attempt has been made to review existing literature, concerned with strength of beam using stiffeners. The literature survey indicates that use of stiffeners in web portion of castellated beams helps in increasing the strength and also minimizing the deflection. Researchers have suggested using stiffener along the edges in order to reduce the stress concentration along openings..
\end{abstract}

Key Words: openings, castellated beam, cellular beam, stiffener, thickness. $* * *$

\section{INTRODUCTION.}

Beams which are provided with opening in the web portion are nothing but castellated beams. Generally the opening provided for castellated beams are circular shaped or hexagonal shaped openings, which are dispersed at regular intervals on the web portion of castellated beam [1]. These are made from hot rolled I-Section which is being cut along certain pattern and then both halves are shifted and re welded such that its depth increases [2]. The beam section obtained is $50 \%$ deeper than the parent I-Section that is 1.5 times the depth of original section [3]. Long span structures as well as vibration characteristics are served best using castellated beam.
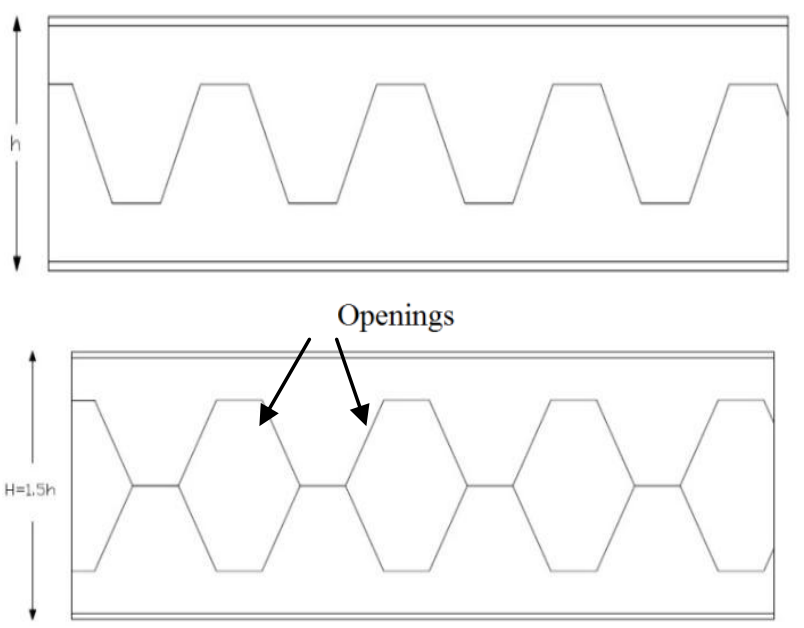

Fig-1: Fabrication process of Castellated Beam with hexagonal openings.

\subsection{Castellated Beams}

Castellated beams are classified according to their shape of openings provided in the web portion. Most common shapes for the openings are hexagonal, circular also called as cellular opening, octagonal, diamond, etc. However due to simplicity in fabrication mostly hexagonal and circular openings of beams are used in industries. Also, most of the research on optimization of hexagonal and circular shape is done. Following figures gives idea about openings provided for castellated beam.

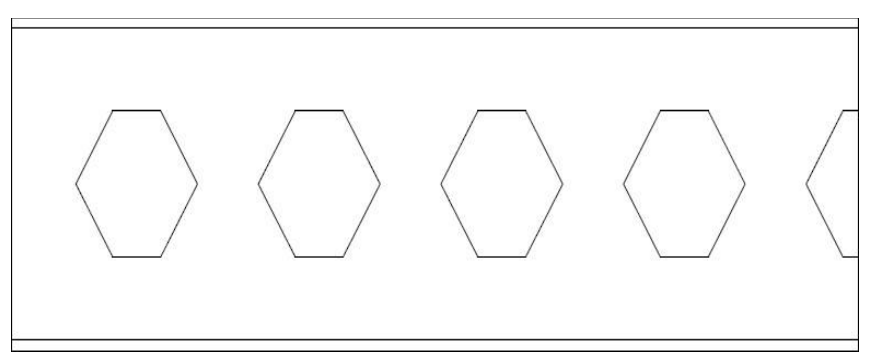

Fig-3: Castellated Beam with Hexagonal Shaped opening

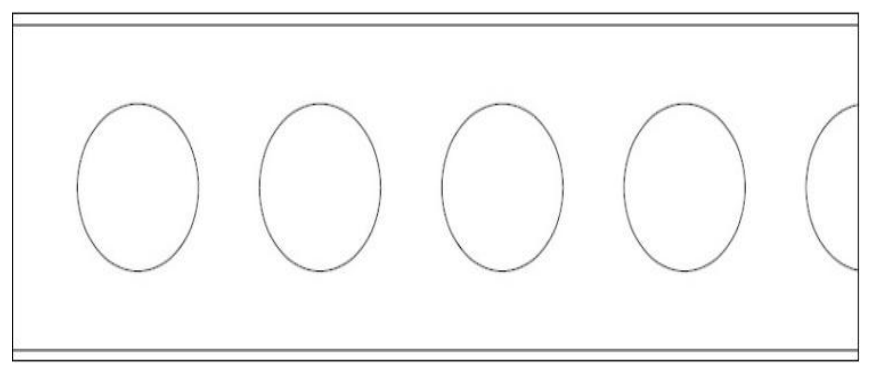

Fig-4: Castellated Beam with Circular Shaped opening 


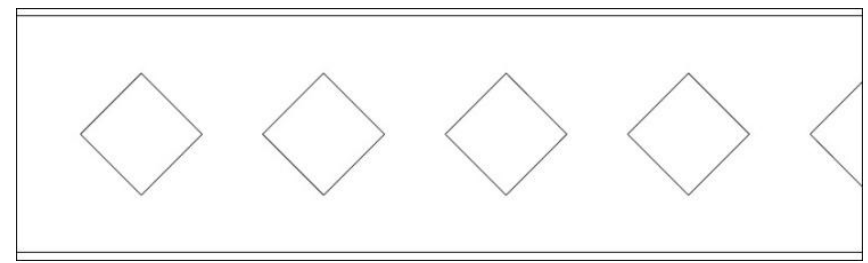

Fig-5: Castellated Beam with Diamond Shaped Opening

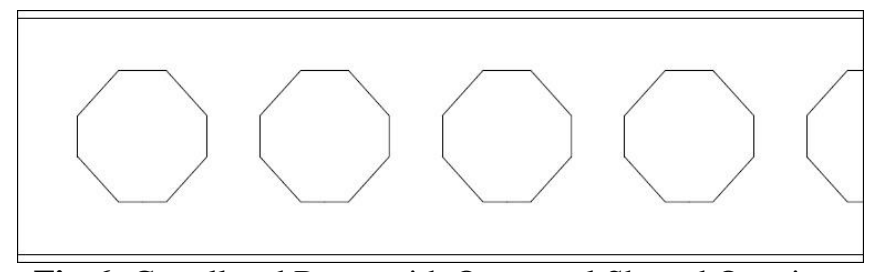

Fig-6: Castellated Beam with Octagonal Shaped Opening

\subsection{Stiffeners}

Stiffener are those structural components which are used to strengthen shear and moment resistance of steel plates along the longitudinal, transverse [Fig - 7, Fig - 9] or/and along the edge of opening [Fig - 8, Fig - 10] [4]. But if the castellated beams are subjected to concentric loading (for example Gantry girders) in such case castellated beam prove to be inappropriate. In such cases castellated beams must be reinforced at the places where these load concentrations occur. For example by inserting plates called as stiffeners, into one or more of the web openings by additional fitting and welding work.

It is observed that there is no regulated knowledge of how a beam with web openings would behave if a stiffener is placed. A computational finite element (FE) analysis and a parametric study of a stiffened castellated beam with web openings, is essential to understand its behaviour

The various types of stiffeners are used for I Beam or castellated beam are as listed below [5]:

[1]. Intermediate transverse web stiffener: Intermediate transverse stiffener may be placed either at one side of web portion or can also be provided on both side of web portion. The buckling strength of web can be increased due to these stiffeners.

[2]. Load carrying stiffener: Load carrying stiffeners are allowed when the load applied to the section is greater than that of the buckling strength of the web. These stiffeners are so designed that the buckling of web can be avoided, which is caused because of intense loading.

[3]. Bearing stiffener: Bearing stiffener are placed where the capacity of the web is less than that of the load applied on the flange portion. These stiffeners helps to minimize the local crushing which is caused because of the loads applied to the specimen.

[4]. Torsion stiffener: Torsion stiffener is provided in such manner that the tensile force can be simply transmitted through the web portion.

[5]. Diagonal stiffener: Diagonal stiffeners are provided in order to bear the shear applied which more than that of the web of the beam. The stiffener provided have different strength that of the web of the beam.

[6]. Transverse stiffener: These stiffeners are used at end and stiffeners at internal supports should normally be doubled sided and symmetric about the centerline of the web [6].

There are some stiffeners which may be effective for performing behavior one or more functions of other stiffeners for which it is designed [5].

\section{EXISTING LITERATURE}

Various research studies are carried out for analysis and design of castellated beams with and without the use of stiffeners are presented in the following section:

Hideo Takabatake, et.al., (1991) [7] experimentally investigated the lateral buckling behavior of I beam with and without using stiffeners in the web portion of the beam. The beams provided with stiffeners and batten plates were placed at different positions along the length of the beam. The beam was restrained against twisting and lateral translation. From the experimental study it was observed that lateral buckling of I beam was delayed due to web stiffeners and battens

Sung C. Lee, et. al., (2002) [8] analyzed three models of plate girder without stiffener using software program. And the same model providing with three plates stiffener are evaluated. The post buckling behavior of shear web panel was explained using model called as shear analogy It was found that the transverse stiffeners are not subjected to compression force. But the strength of the intermediate transverse stiffener is very important parameter as it provides strength to the web of the beam.

Ehab Ellobody (2011) [9] studied the interaction of buckling modes in castellated beam with hexagonal opening analytically as well as experimentally. 96 models of castellated beam were developed with all non linear material properties in ABAQUS Finite Element programming software. The parametric study was extended in order to study the effects on the beam when the geometries of the specimen is changed also the length of the beam was considered. The strength of the steel and the non dimensional slenderness of failure mode were also other two parameters considered in order to study the effect. The study showed that load of failure of the beam is reasonably reduced due to presence of web distortional buckling. The load carrying capacity is directly proportional to the strength of steel hence offers considerably increase in failure load. It was observed that normal strength castellated beam generally fails in lateral torsional buckling, while high strength castellated beam fails by web distortional buckling.

Konstantinos Daniel Tsavdaridis and Cedric D’Mello (2011) [10] studied the performance, modes of failure and the load carrying capacity of various types of cellular beams analytically as well experimentally, providing web openings at close spacing. The beams were stiffened with stiffener at support as well as at the mid span of the specimen in order 
to prevent lateral torsional buckling. The beams were simply supported and monolithic loading was applied at the mid span of section. A High shear was detected at web post along with heavy distortion of web openings and also the additional deformation was examined at the loading point. Investigators conclude that no absolute study has been carried out on the stability of stiffeners and equilibrium problem.

M. R. Soltani et. Al., (2011) [1] investigated behavior of perforated beam in order to study the web post buckling The shapes considered for the openings were hexagonal and octagonal shapes. The researchers have developed a mathematical model was developed by the researchers in order to determine the buckling failure of that perforated beam by using MSC/NASTRAN software. The analytical study was carried out considering the factors such as depth of opening, dimension of web and yield stress of the material by varying each of these factors and by keeping others constant. Similar study was also carried out on castellated beam which was provided with intermediate plates (stiffeners). The boundary condition for all beams which were tested was supported simply while the load was applied at top of the flange. The experimental tests were also carried out for better results and validation. The results showed that thin webbed castellated beam exhibits web post buckling with limited plastic zone.

Ehab Ellobody (2012) [11] analyzed the castellated beam with circular openings by nonlinear analysis, where the combined modes of buckling of these beams were considered. The behavior was checked for high strength of beam by considering the parameters like imperfection of geometry, remaining stresses and also non linear material properties of material were considered. The non linear finite element method helped in predicting deflection, failure modes and also the loads causing failure. The result of parametric study shows the cellular beam fails because of combined action of web distortional as well as due to web post buckling mode which shows considerably decrease in failure load. Lateral torsional buckling was observed in cellular beams with normal strength while distortion of web and also the web post buckling was observed in cellular with high strength.

Wakchaure M.R. et. al. (2012) [12] carried out experimental investigation on simply supported hexagonal castellated beam under two point loading. Modes of failure of the castellated were examined for different depths of openings. From the experimentation, researchers conclude that the castellated beam behaves satisfactorily up to a maximum depth of 0.6 times the depth of opening (0.6D). Investigators recommend for providing reinforcement (stiffeners) in order to avoid Vierendeel effects caused due to openings.

B. Anupriya and Dr. K. Jagadeesan (2013) [3] studied analytically shear strength and deflection properties of castellated beams with hexagonal openings using ANSYS14. Study shows that, as the depth of castellated beam increases, the stress concentration at corners as well as at the loading point increases. In order to avoid this, study was also carried out by provision of diagonal stiffeners and also with diagonal and vertical stiffeners (i.e. combined form) in the openings. The results indicate that minimum deflections occur in the castellated beam provided with diagonal and vertical stiffeners (combined form).

Delphine Sonck and Jan Belis (2014) [2] investigated lateral torsional buckling behavior of cellular beams for various spacing of cellular openings using ABAQUS Software and was validated using experimental result where only lateraltorsional buckling failure was considered. The specimens were simply supported and two point loadings were applied. It was observed that I section with evenly spaced circular web opening proved to be the best in strong axis bending also it proved to be holding good in experimental results. Study was extended to the parametric study for new design approach using current convention method and considering European code guidelines.

Jamadar A. M. and Kumbhar P. D. (2015) [13] carried out experimentally as well as analytically using Abaqus (CAE 6.13) of castellated beams provided with circular and diamond shaped openings by following the guidelines given in EUROCODE 3. The software results were validated by comparing it with experimental results. The result indicates that the castellated beam with diamond shaped opening suffers least amount of local failure as more shear transfer area is available as compared to the castellated beams with circular opening. Also load carrying capacity is greater for diamond shape than circular opening.

Ajim S. Shaikh and Harshal R. Aher (2015) [14], studied basic behavior of the cellular beam using finite element method for two point loading where the boundaries were simply supported. During investigation it was observed that on top of openings and below openings stress concentration was developed in more amounts. So, it was suggested to add extra plates to overcome the stability problem during erection.

Konstantinos Daniel Tsavdaridis and Grigorios Galiatsatos (2015) [4] studied computational models of cellular beams using Finite Element Program. The behavior of cellular beams was done on the basis of opening of cellular beam. The behavior of these web openings was studied by other two parameters namely thickness of web and thickness of stiffener of $20 \mathrm{~mm}$ which were placed at the top and bottom, between flange and web connection. It was recommended that the stiffeners are viable only for s/d ratio between 1.2 and 1.3. It was also suggested to provide ring stiffener (along edge of opening) [Fig-10] for opening with $\mathrm{s} / \mathrm{d}>1.3$. Also behavior of transverse stiffener full or partial depth was recommended for further studies.

\section{RESEARCH GAP}

From the literature survey, it can be observed that a lot of study has been carried out in optimizing the dimensions of perforated web steel beams with hexagonal, octagonal, square, circular, etc opening in respect of flexural behavior. 
But it has been observed that due to simplicity or ease of the fabrication hexagonal and the circular type of openings are employed maximum in industries.

Also, most of the studies have indicated that the failure of web perforated beams has occurred due to local failures in the web portion. However, very little work has been done to avoid failure of castellated beams, it has been suggested to provide stiffener with proper dimensions and locations. The strength enhancement is important in case where load concentration is observed in the beam. The castellated beam is good in carrying distributed loads but fails to carry high concentrated loads. The behavior and failure modes are necessary to be checked using stiffeners in the appropriate place so that the efficiency of the beam is increased in worst condition of stress concentration. In Indian standards there are no provisions for the stiffeners for castellated beam while it is to be studied in detail from the other codes and guidelines are needed to be developed for the design of the stiffeners.

The future scope defined by few researchers in papers give a rough idea of good performance of the castellated beam using stiffeners. Also this performance will enhance strength and torsional behavior when designed with stiffeners.

\section{CONCLUSIONS}

Study and optimization of the castellated beam is done by many researchers. From the research gap we can frame a conclusion that the study of the behavior of the castellated beam with stiffener is not yet understood. But on the other hand the day by day use of the castellated beam is increasing widely and demand of good performance of the beam under point loading is increasing. This will also give a rise to a new area of optimizing the design of stiffener.

From the review of literature following conclusions can be drawn:

1. Analysis and design of castellated beam needs to be carried out by using stiffeners in transverse direction and also along the edge of openings in order to minimize web post buckling.

2. Optimization of castellated beams with stiffeners by varying the parameters namely, size and positions in web portion is necessary.

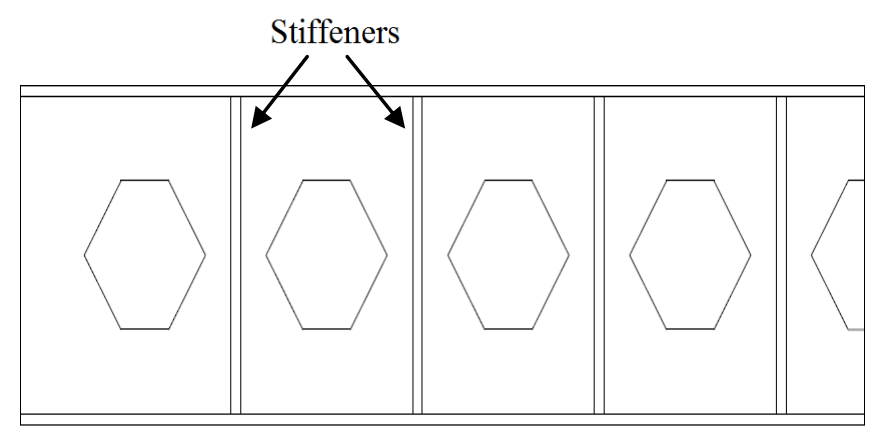

Fig-7: Hexagonal Castellated Beam with stiffeners in transverse direction

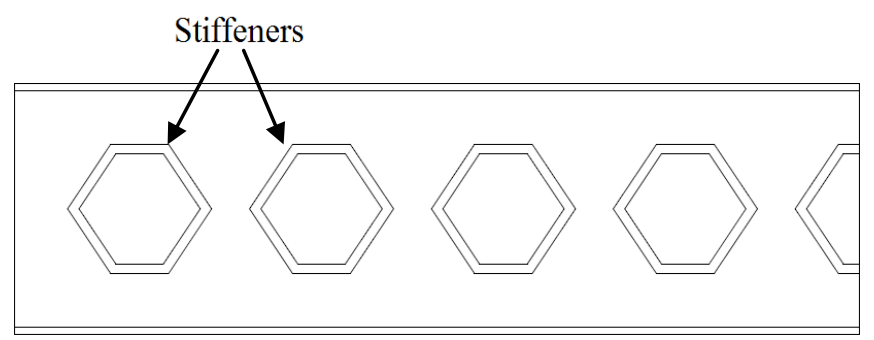

Fig-8: Hexagonal Castellated Beam provided with Stiffeners along edge of openings

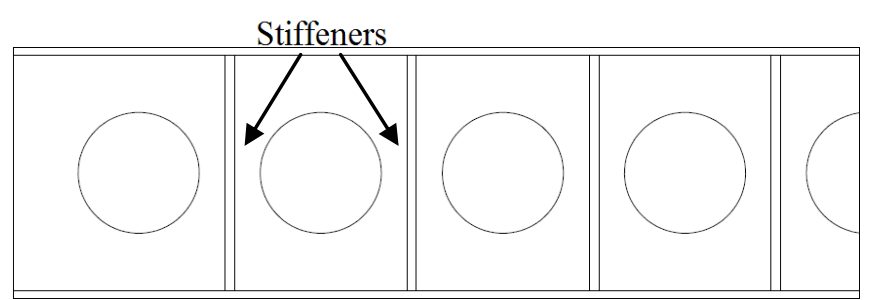

Fig-9: Cellular Beam provided with stiffener in transverse direction.

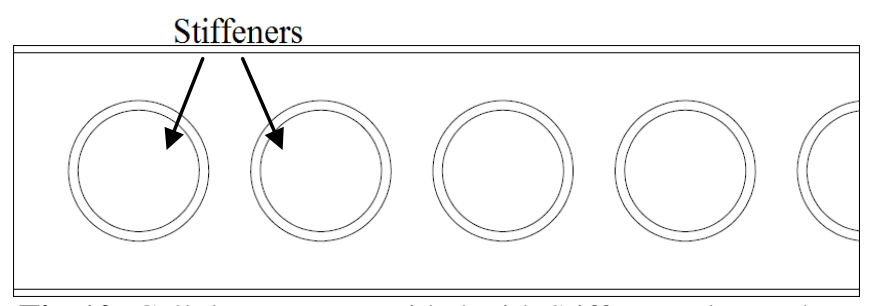

Fig-10: Cellular Beam provided with Stiffeners along edge of openings

\section{REFERENCES}

[1]. M.R. Soltani, A. Bouchaïr, M. Mimoune, "Nonlinear FE Analysis of the Ultimate Behavior of Steel Castellated Beams", Journal of Constructional Steel Research, vol.70, pp 101-114. 2012.

[2]. Delphine Sonck and Jan Belis, "Lateral-torsional buckling resistance of cellular beams", Journal of Constructional Steel Research, vol.105, pp 119-128. 2015.

[3]. B. Anupriya and Dr. K. Jagadeesan, "Strength Study on Castellated Beam", International Journal on Engineering Research \& Technology, Vol.2, pp 3853-3859. 2013.

[4]. Konstantinos Daniel Tsavdaridis and Grigorios Galiatsatos, "Assesment of Cellular Beams with Transverse Stiffeners and Closely Spaced Web Openings", Thin-Walled Structures, vol.94, pp 636650. 2015.

[5]. Indian Standard code of practices for General construction in steel, IS 800-2007, third revision, bureau of Indian standards.

[6]. EC3. Eurocode 3: Design of steel structures part1-1, General rules for buildings. London (UK), British standard institution BS EN 1993-1-1,2005.

[7]. Hideo Takabatake, Shigeru Kusumoto and Tomitaka Inoue, "Lateral Buckling Behavior of I Beams Stiffened With Stiffeners", Journal of Structural Engineer, Vol.117, pp 3203-3215. 1991. 
[8]. Sung C. Lee, M. ASCE; Chai H. Yoo and Dong Y. Yoon, "Behavior of Intermediate Transverse Stiffeners Attached on Web Panels", Journal of Structural Engineering, Vol. 128, pp 337-345. 2002.

[9]. Ehab Ellobody, "Interaction of Buckling Modes in Castellated Steel Beams ", Journal of constructional steel research, Vol. 67, pp 814-825. 2011.

[10]. Konstantinos Daniel Tsavdaridis and Cedric D'Mello, "Web Buckling Study of the Behavior and Strength of Perforated Steel Beams with Different Novel Web Opening Shapes", Journal of Constructional Steel Research, vol.67, pp 1605-1620. 2011.

[11]. Ehab Ellobody, "Nonlinear analysis of cellular steel beams under combined buckling modes", Thin walled structures, Vol. 52, pp 66-79. 2012.

[12]. Wakchaure M.R., Sagade A.V. and Auti V.A., "Parametric Study of Castellated Beam Varying Depth of Web Opening", International Journal of Scientific and Publications, Vol. 2,pp 1-5. 2012.

[13]. Jamadar A. M. and Kumbhar P.D., "Parametric Study of Castellated Beam with Circular and Diamond Shaped Openings", International Research Journal of Engineering and Technology, Vol.02, pp 715-722. 2015.

[14]. Ajim S. Shaikh and Harshal R. Aher, "Structural Aanalysis of Castellated Beam", International Journal on Recent Technologies in Mechanical and Electrical Engineering, Vol.2,pp 081-084. 2015.

\section{BIOGRAPHIES}



Siddheshwari A. Patil, PG Scholar (Civil Structure), Department of Civil Engineering, RIT Rajaramnagar, Sangli, Maharashtra, India.

Email:patil.siddheshwari@gmail.com

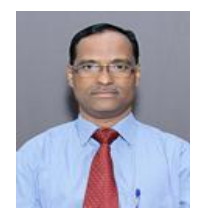

Popat D. Kumbhar, Associate Professor, Department of Civil Engineering, RIT Rajaramnagar, Sangli, Maharashtra, India. Email: Popat.kumbhar@ ritindia.edu 